Original Article

\title{
Morphometric measurements and carcass characteristics of Black Australorp, Naked Neck, and Rhode Island Red crossbreds under alternative production systems
}

\author{
Medições morfométricas e características de carcaça de Black Australorp, Naked Neck \\ e Rhode Island Red crossbreds sob sistemas de produção alternativos
}

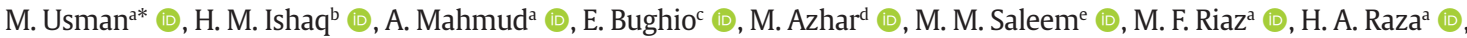 \\ M. Hussaina (D), H. R. A. Latifa (D) and S. Ahmada* (D) \\ aUniversity of Veterinary and Animal Sciences, Faculty of Animal Production and Technology, Department of Poultry Production, Lahore, \\ Pakistan \\ bBahauddin Zakariya University, Faculty of Veterinary Sciences, Department of Livestock and Poultry Production, Multan, Pakistan \\ 'Shaheed Benazir Bhutto University of Veterinary and Animal Sciences, Faculty of Animal Production and Technology, Department of Poultry \\ Production, Sakrand, Pakistan \\ dPoultry Research Institute, Rawalpindi, Pakistan \\ eUniversity of Veterinary and Animal Sciences, College of Veterinary and Animal Sciences, Narowal, Pakistan
}

\begin{abstract}
The present trial explained the effect of alternative production systems on growth, morphometric and carcass traits of four different chicken genotypes. The second generation of two genotypes RNN (Rhode Island Red $\times$ Naked Neck) and BNN (Black Australorp $\times$ Naked Neck) obtained by two self-crosses $($ RNN $\times$ RNN $=$ RR and BNN $\times$ BNN $=B B)$ and two reciprocal crosses $(\mathrm{RNN} \times \mathrm{BNN}=\mathrm{RB}$ and $\mathrm{BNN} \times \mathrm{RNN}=\mathrm{BR})$ were evaluated in three alternative production systems (conventional cages, enriched cages, and aviary). At the $6^{\text {th }}$ week of age after sexing, a total of 600 birds, comprising 150 from each crossbred with a total of 300 pullets and 300 cockerels were divided into conventional cages, enriched cages, and aviary systems having 200 birds in each.Birds were organized into $3 \times 4$ factorial arrangements under Completely Randomized Design ( 3 production systems $\times 4$ genotypes $\times 2$ sexes $\times 25$ birds $=600$ birds). Regarding genotypes, RB and BR males showed higher $(\mathrm{p}<0.01)$ carcass yield, drumstick weight, breast weight, and thigh weight than BB and RR genotypes. Females of BR genotype showed higher $(p<0.01)$ breast weight, thigh weight and drumstick weight. As far as production systems are concerned, higher $(\mathrm{p}<0.01)$ liver weight, heart weight, breast weight, intestinal weight, drumstick weight, and thigh weight were observed in the males reared in enriched cages compared with conventional cages and aviary system. Females reared in enriched cages showed higher $(\mathrm{p}<0.01)$ heart weight, breast weight, intestinal weight, drumstick weight, and thigh weight when compared with those reared in conventional cages and aviary. It is concluded that chickens (both sexes) of BR and RB genotypes had better morphological measurements and carcass traits than those of RR and BB genotype chickens. Among alternative production systems, chickens reared in enriched cages had better traits than those of reared in conventional cages and aviary during the growing phase.
\end{abstract}

Keywords: crossbred chickens, alternative production systems, carcass traits, morphometric, measurements.

\begin{abstract}
Resumo
O presente estudo explicou o efeito de sistemas alternativos de produção sobre o crescimento, características morfométricas e carcaças de quatro genótipos de frango diferentes. A segunda geração de dois genótipos RNN (Rhode Island Red $\times$ Naked Neck) e BNN (Black Australorp $\times$ Naked Neck) obtida por duas autocruzes $(\mathrm{RNN} \times \mathrm{RNN}=\mathrm{RR}$ e B ANN $\times$ BNN $=\mathrm{BB})$ e duas cruzes recíprocas $(\mathrm{RNN} \times \mathrm{BNN}=\mathrm{RB}$ e BNN $\times \mathrm{RNN}=\mathrm{BR})$ foi avaliada em três sistemas de produção alternativos (gaiolas convencionais, gaiolas enriquecidas e aviário). Na 6aㅗ semana de idade após 0 sexo, um total de 600 aves, compostas por 150 de cada raça cruzada com um total de 300 pullets e 300 galos, foi dividido em gaiolas convencionais, gaiolas enriquecidas e sistemas aviários com 200 aves em cada. As aves foram organizadas em $3 \times 4$ arranjos fatoriais sob projeto completamente randomizado ( 3 sistemas de produção $\times 4$ genótipos $\times 2$ sexos $\times 25$ aves $=600$ aves). Em relação aos genótipos, os machos RB e BR apresentaram maior rendimento de carcaça $(\mathrm{p}<0,01)$, peso da baqueta, peso mamário e peso da coxa do que os genótipos BB e RR. As fêmeas do genótipo BR apresentaram maior $(\mathrm{p}<0,01)$ peso mamário, peso da coxa e peso da baqueta. No que diz respeito aos sistemas de produção, maior $(\mathrm{p}<0,01)$ peso hepático, peso cardíaco, peso mamário, peso intestinal, peso da baqueta e peso da coxa foram observados nos machos criados em gaiolas enriquecidas em comparação
\end{abstract}

*e-mail: musman@uvas.edu.pk; sohail.ahmad@uvas.edu.pk

Received: May 25, 2021 - Accepted: June 29, 2021

This is an Open Access article distributed under the terms of the Creative Commons Attribution License, which permits unrestricted use, distribution, and reproduction in any medium, provided the original work is properly cited. 
com gaiolas convencionais e sistema aviário. As fêmeas criadas em gaiolas enriquecidas apresentaram maior ( $\mathrm{p}<0,01$ ) peso cardíaco, peso mamário, peso intestinal, peso da baqueta e peso da coxa quando comparadas com as criadas em gaiolas convencionais e aviárias. Conclui-se que as galinhas (ambos os sexos) dos genótipos BR e RB apresentaram melhores medidas morfológicas e traços de carcaça do que os de frangos genótipos RR e BB. Entre os sistemas de produção alternativos, as galinhas criadas em gaiolas enriquecidas tinham características melhores do que as criadas em gaiolas convencionais e aviárias durante a fase de cultivo.

Palavras-chave: galinhas de raça cruzada, sistemas de produção alternativos, traços de carcaça, morfométrica, medidas.

\section{Introduction}

Native chicken breeds in traditional extensive production systems are integral part of the poultry production in developing countries (Ghayas et al., 2020). These chickens are famous for better adaptability to the local environment (Batool et al., 2018) and their perpetuate role in breaking the vicious cycles of nutritional scarcities in developing countries (Terfa et al., 2019). However, due to unplanned and haphazard crossing in village farming systems, the traits of economic importance in these birds are not feasible for enough profit generation. Such quantitative characteristics like, body weight, growth and egg production can be value-added by improving genetics and housing conditions (Ndegwa and Kimani 1997; Okeno et al., 2011; Havenstein et al., 2003 a, b). Selection and crossbreeding are the most accurate and adapted methods to get genetically superior chickens in successive generations (Bungsrisawat et al., 2018). These practices may result in changes in morphometric and carcass traits (Bungsrisawat et al., 2018; Ahmad et al., 2019). For example, Keel bone structure is significantly influenced by genetic background and husbandry systems (Eusemann et al., 2020). In a previous study, body weight and breast meat yield in 16 week old Betong chickens were found to be highly inheritable traits (heritability $=0.45$ and 0.50 respectively) that showed the potential of such traits for enhanced meat yield from the selected birds (Bungsrisawat et al., 2018).

Crossing the indigenous germplasm with exotic breeds can result in the improvement of production performance, carcass and reproductive traits and better acclimatization to local environment (Adebambo et al., 2011; Khawaja et al., 2013). Genetic manipulations for enhanced production may result in modification of overall physiology of chicken's body as observed in commercial broilers (Tallentire et al., 2016; Hartcher and Lum, 2020) and layers (Rowland et al., 2019). To maintain the physiological status of genetically selected birds, one should also make suitable changes to the rearing system that can help the birds to perform according to the genetic potential by maintaining their metabolic physiology (Preisinger, 2005).

In Pakistan, Rhode Island Red (RIR) and Naked Neck chickens are preferred genotypes among the rural community and in most cases live in scavenging conditions (Sadef et al., 2015). However, Naked Neck chicken is believed to be more suitable because of more adaptability to harsh climate (Melesse et al., 2011). Some rural farmers keep them in indoor cages for more profitability. Although, these conventional cages have some advantages in terms of higher output by enhanced production from the birds, however, there are reports that describe these cages as an unfriendly environment especially from bird welfare point of view. Since the ban from European countries on these cages in 2012 (Appleby, 2003), animal welfare organizations are putting more emphasis on replacement of this system with welfare friendly alternative production systems. Considering such scenarios, efforts were made to mitigate the effect of total confinement of the birds by rearing them in aviary and enriched cages (Leyendecker et al., 2005; Pohle and Cheng, 2009). In an enriched cage, facilities for dust bath, nesting and walk are provided within the cage (Sosnówka-Czajka et al., 2010). But, their potential use in newly developed crossbreds of Naked Neck, RIR and Black Australorp has never been studied earlier. Keeping in mind the expected outcome of genetic structuring and the need for suitable rearing systems, it was hypothesized that the morphometric and carcass traits in Naked Neck chicken crossbreds will differ under aviary, conventional cage and enriched cage systems.

\section{Material and Methods}

The study evaluated the performance of crossbreds of Naked Neck (NN), Black Australorp (BAL) and Rhode Island Red (RIR) under alternative production systems i.e., conventional cages, aviary system, and enriched cages. The study was conducted at the Indigenous Chicken Genetic resource Centre (ICGRC), Department of Poultry Production, UVAS, Ravi Campus Pattoki. This city is located at $73^{\circ} 50$ ' $60 \mathrm{E}$ and $31^{\circ} 1^{\prime} \mathrm{ON}$ with an altitude of $610 \mathrm{ft}(186 \mathrm{~m})$ and normally experiences tropical hot and humid climate where the temperature ranges between 12 to $45^{\circ} \mathrm{C}$.

\subsection{Statement of animal rights}

All the procedures performed in this study was in accordance with the ethical standards of the University of Veterinary and Animal Sciences, Lahore, Pakistan and approval was granted by the Animal Ethical Review Committee.

\subsection{Population size and experimental design}

The present study was a continuation of the previous research, in which the performance of progeny (F1) was taken from Rhode Island Red $\times$ Naked Neck $($ RNN) and Black Australorp $\times$ Naked Neck $(B N N)$ was evaluated (Ahmad et al., 2019). In the present study, the second generation (F2) of these crossbreds (BNN and RNN) were evaluated in reciprocal crosses. For this purpose, a total of 200 heterozygous partial feather chickens (discarding homozygous full feathered and homozygous naked neck) comprising 50 birds ( $10 \hat{\sigma} \times 40$ 우) from each crossbred 
of the first generation i.e., Crossbred I (BNN $0 \times$ BNN $o$ ),

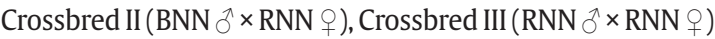
and Crossbred IV ( $\mathrm{RNN} \gamma \times \mathrm{BNN} \uparrow$ ) were used to take more than 1200 hatching eggs at $33^{\text {rd }}$ week of age (see Figure 1 ) (Usman et al., 2020). A total of 720-day-old chicks in the second generation, 180 from each Crossbred (BB, BR, RR and RB) hatched at Avian Research and Training Centre (ARTC), UVAS, Lahore was transported to ICGRC, Ravi Campus, UVAS, Pattoki. Birds were fed commercial breeder ration formulated according to the recommendations of Leeson and Summers (2005). Brooding the chicks was carried out under standard management conditions up to 6 weeks of age (WOA). During the brooding phase, birds were vaccinated against Infectious Bronchitis and Newcastle Disease at the $15^{\text {th }}$ day of age according to the local area schedule.

At the $6^{\text {th }}$ week of age after sexing, a total of 600 out of 720 birds, comprising 150 from each crossbred with a total of 300 pullets and 300 cockerels were divided into conventional cages, enriched cages and aviary system having 200 birds in each. Birds were assigned to treatments in a $3 \times 4$ factorial arrangements in Completely Randomized Design ( 3 production systems $\times 4$ genotypes $\times 2$ sexes $\times 5$ replicates $\times$ 5 birds $=600$ birds $)$.

\subsection{Production systems}

Chickens reared in enriched cages and aviary systems were provided with perches and dust bathing area. Open sided windowed enclosures ventilated with ceiling fans were used for aviaries and enriched cages. Galvanized round feeders and plastic manual drinkers were used in aviaries and enriched cages (as shown in Table 1). Birds reared in conventional cage system were maintained in environmentally controlled poultry shed equipped with galvanized three-tiered battery cage system, automatic manure belt, automatic water nipple line, and feed trolley (FACCO, Poultry Equipment-C3). The supply of fresh water was ad libitum; chickens were fed commercial formulated diet (as shown in Tables 2,3).

\subsection{Housing conditions}

The duration of the experiments was 2.5 months (March to May) during which the minimum to maximum temperature and humidity were maintained between the range of 26 to $34^{\circ} \mathrm{C}$ and 59 to $76 \%$, respectively, inside open sided enclosures. In environmentally control houses the minimum and maximum temperature and humidity ranged between 19 to $28^{\circ} \mathrm{C}$ and 64 to $79 \%$, respectively.Chickens reared in enriched cages and aviaries were provided with natural day length (see Figure 2). The lighting schedule for the conventional cage system was applied according to Hyline W36 Management Guide (HY-LINE, 2018). Rice husk was used as litter material in both enriched cages and aviaries. Approximately 4 inches depth of bedding material was maintained and racking on daily basis was ensured to maintain desirable better conditions.

\subsection{Parameters evaluated}

Data were collected for morphometric measurements on weekly basis during the rearing phase from 7 to 16 weeks.

\section{Population Size}

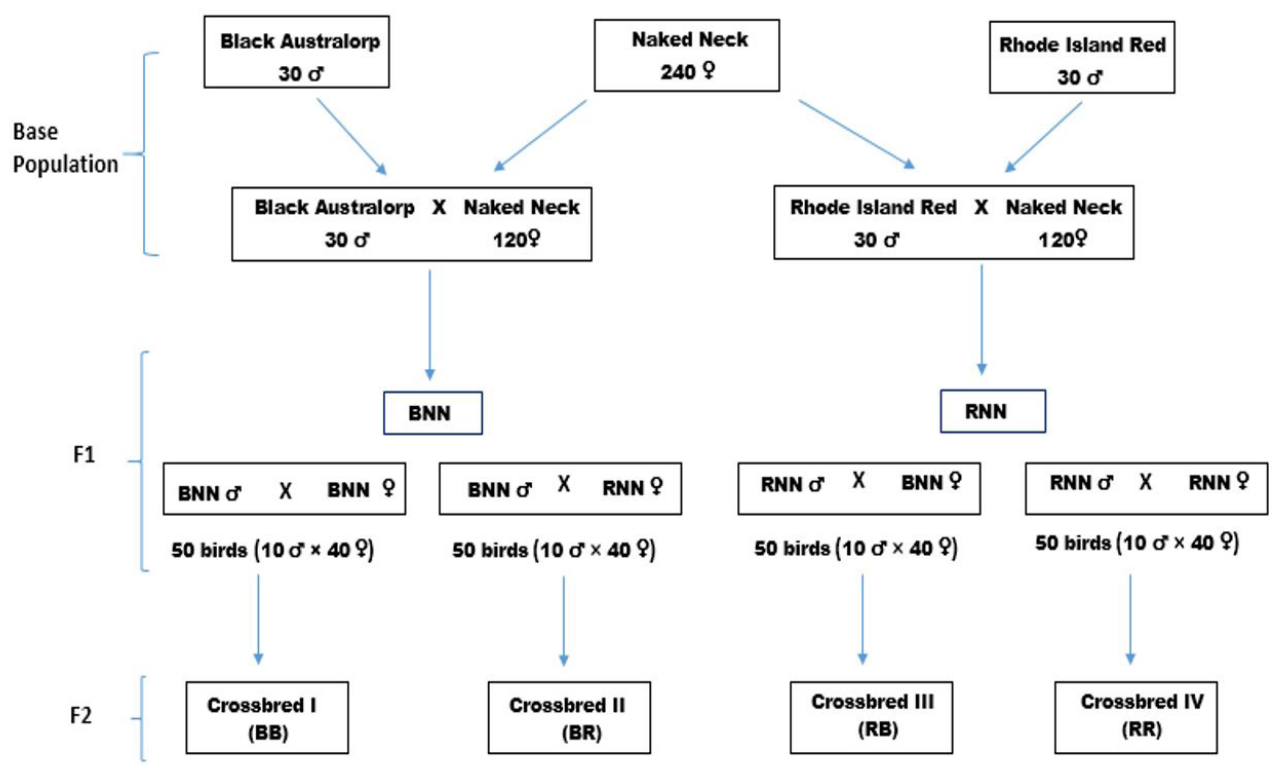

Only heterozygous partial feather chicken were used in each generation

Figure 1. Breeding plan for Crossbreeding of Naked Neck, Black Australorp and Rhode Island Red Chickens. 


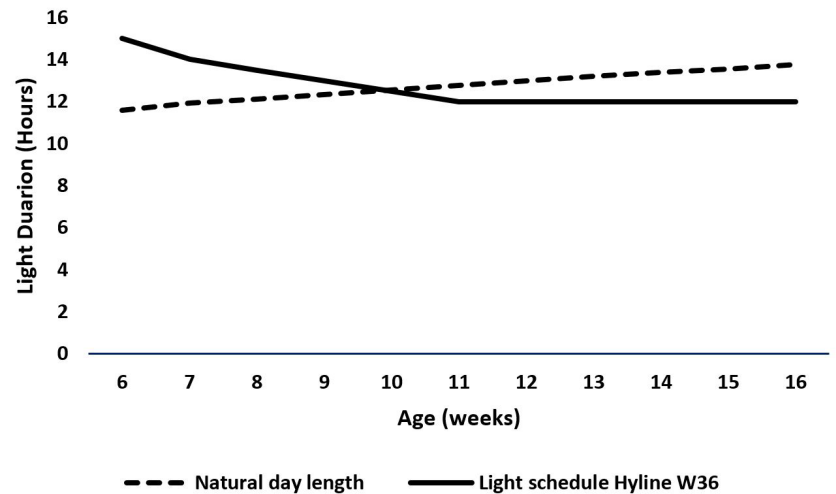

Figure 2. Lighting schedule for experimental birds.

Table 1. Physical characteristics of alternative production systems.

\begin{tabular}{|c|c|c|c|}
\hline Specifications & $\begin{array}{c}\text { Conventional cage } \\
\text { (Separate for each sex) }\end{array}$ & $\begin{array}{c}\text { Enriched cage } \\
\text { (Separate for each sex) }\end{array}$ & Aviary (Straight run) \\
\hline $\begin{array}{c}\text { Dimensions } \\
(\text { Length } \times \text { Depth } \times \text { Height })(\mathrm{cm})\end{array}$ & $60.9 \times 76.2 \times 60.9$ & $91.4 \times 91.4 \times 91.4$ & $304.8 \times 304.8 \times 304.8$ \\
\hline Stocking Density & 5 birds/ cage & 5 birds/cage & 50 birds / aviary \\
\hline Floor space per bird $\left(\mathrm{cm}^{2}\right)$ & 931.9 & 1672 & 1858 \\
\hline $\begin{array}{l}\text { Dimensions of Dust bathing } \\
\text { Area (Length } \times \text { width) }(\mathrm{cm})\end{array}$ & & $55 \times 25.3$ & $137 \times 137$ \\
\hline Dust bathing Space/bird $\left(\mathrm{cm}^{2}\right)$ & ------------------------ & 276 & 376 \\
\hline \multicolumn{4}{|c|}{ Perches } \\
\hline Number & -------------------------- & 1 & 2 \\
\hline Material & ------------------------ & Wooden & Wooden \\
\hline Shape & 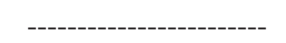 & Round & Round \\
\hline Diameter $(\mathrm{cm})$ & --------------------------- & 1.8 & 4.2 \\
\hline Length $(\mathrm{cm})$ & & 121.9 & 304.8 \\
\hline Height from floor $(\mathrm{cm})$ & & 45.7 & 91.4 \\
\hline
\end{tabular}

Table 2. Weekly feed allowance ( $\mathrm{g}$ / bird) during growing phase.

\begin{tabular}{cc}
\hline Age (weeks) & Daily feed allowance $(\mathrm{g})$ \\
\hline 7 & 24 \\
8 & 28 \\
9 & 30 \\
10 & 30 \\
11 & 34 \\
12 & 36 \\
13 & 38 \\
14 & 38 \\
15 & 40 \\
16 & 42 \\
\hline
\end{tabular}

Measurements taken included body, keel, drumstick and shank length, wing spread and drumstick, and shank circumference. All measurements were taken using a measuring tape. Body weight was measured by using an electronic weighing balance (Weigh South WBT-602 made in China). The carcass traits were measured at the end of the growing phase (16 weeks) by Halal slaughtering of 96 birds ( 48 cockerels and 48 pullets; 4 birds from each treatment group) randomly picked from the population. Carcass traits measured were drumstick, thigh, breast, wings, and giblets weight (gizzard, liver, and heart) (Raphulu et al., 2015).

\subsection{Statistical analysis}

Effect of production systems and genotype on morphometric measurements and carcass traits were evaluated by two-way ANOVA technique. General Linear Model of SAS was used (SAS software version, 9.1). Production systems and genotype were considered as main effects and their interaction was also tested. Tukey's Kramer test (Tukey, 1953) was employed to compare treatment means at a significance level of $\mathrm{p} \leq 0.05$. The following statistical model was used:

$$
Y_{i j k}=\mu+P_{i}+G_{j}+(P \times G)_{i j}+\epsilon_{i j k}
$$


Table 3. Nutrition value and composition of experimental ration during growing phase.

\begin{tabular}{cc}
\hline Nutritive value & Grower (7-16 weeks) \\
\hline $\mathrm{CP}(\%)$ & 14 \\
$\mathrm{ME} \mathrm{(Kcal/Kg)}$ & 2850 \\
$\mathrm{Ca}(\%)$ & 0.87 \\
$\mathrm{Av} . \mathrm{P}(\%)$ & 0.38 \\
Lysine (\%) & 0.70 \\
Methionine (\%) & 0.30 \\
Na (\%) & 0.19 \\
\hline Feed Ingredient (\%) & \\
\hline Corn & 61.55 \\
Soybean Meal & 31.70 \\
Soybean Oil & 3.00 \\
DCP & 1.70 \\
NaCl & 0.30 \\
Methionine & 0.12 \\
Total & 100 \\
\hline
\end{tabular}

Where,

$\mathrm{Y}_{\mathrm{ijk}}=$ Observation of dependent variable recorded on $\mathrm{i}^{\text {th }}$ Production System and $\mathrm{j}^{\text {th }}$ Genotype

$\mu=$ Population mean

$\mathrm{P}_{\mathrm{i}}=$ Effect of $\mathrm{i}^{\text {th }}$ Production System $(\mathrm{i}=1,2,3)$

$\mathrm{G}_{\mathrm{j}}=$ Effect of $\mathrm{j}^{\text {th }}$ Genotype $(\mathrm{j}=1,2,3,4)$

$(P \times G)_{i j}=$ Interaction between production system and Genotype

$\epsilon_{\mathrm{ijk}}=$ Residual error of $\mathrm{k}^{\text {th }}$ observation on $\mathrm{i}^{\text {th }}$ Production system and $\mathrm{j}^{\text {th }}$ genotype NID $\sim 0, \sigma^{2}$

\section{Results}

\subsection{Body weight and morphometric measurements}

Comparing growth and morphometric measurements (as shown in Tables 4, 5) of different genotypes, chickens (both sexes) of RB and BR genotypes showed higher ( $\mathrm{p}<$ 0.01 ) BW and keel length when compared with BB and RR chicken genotypes. Drumstick length and drumstick circumference of males were higher $(\mathrm{p}<0.0001)$ in both $\mathrm{RB}$ and $\mathrm{BR}$ genotypes than those of $\mathrm{BB}$ and RR genotypes. However, drumstick circumference of females was higher $(\mathrm{p}<0.05)$ in RB and BR genotypes followed by RR and BB genotypes. Drumstick length remained the same $(p>0.05)$ among the females of different genotypes. Shank length of both sexes was observed to be higher $(p<0.05)$ in $R B$ genotype than those of RR, BB and BR genotypes. Wing span of males was observed to be higher $(p=0.05)$ in $R B$ and BR genotypes than those of RR and BB genotypes. However, the difference in wing span of females was not significant $(p>0.05)$ among different genotypes. Although not significant $(p>0.05)$, differences were observed in body length and shank circumference of both males and females.
The body weight of chickens (both sexes) reared in enriched cage system was higher $(p<0.05)$ followed by those reared in conventional cages and aviary system. Drumstick length and drumstick circumference of males reared in enriched cage system were higher $(\mathrm{p}<0.05)$ followed by those reared in conventional cages and aviary system. Non-significant differences ( $p>0.05$ ) were observed on drumstick length of females among different production systems whereas drumstick circumference was observed to be higher $(\mathrm{p}<0.05)$ in enriched cage system followed by conventional cage and aviary systems. Wing span of males reared in the aviary system was higher $(p<0.05)$ than those reared in conventional cages and aviary system. Non-significant differences $(p>0.05)$ were observed among different production systems in terms of body length, shank length, and shank circumference of both sexes. Keel length of females was observed to be higher $(p<0.05)$ in the enriched cage system followed by conventional cage and aviary systems.

The body weight and shank length of males were higher $(\mathrm{p}<0.05)$ in RB and BR genotypes reared in the enriched cage system when compared with other interaction groups. Males of RB genotype reared in enriched cage system showed higher $(\mathrm{p}<0.05)$ drumstick circumference and drumstick length compared with other interaction groups. Males of BR genotype reared in the aviary system showed higher $(p<0.05)$ wingspread than other interaction groups. Although not significant ( $p>0.05$ ), differences in interaction means of body length, keel length, and shank circumference of males were observed. Moreover, similarities $(p>0.05)$ in body length, shank length, shank circumference, drumstick length, drumstick circumference, and wing spread of females were observed among different interaction groups. Body weight of females from RB and BR genotypes reared in the enriched cage system was observed to be higher $(\mathrm{p}<0.05)$ when compared with other interaction groups. Keel length of females from RB genotypes reared in the enriched cage system was observed to be significantly higher $(\mathrm{p}<0.05)$ than other interactions.

\subsection{Carcass traits}

Significant differences were observed in carcass traits of different genotypes reared in alternative production systems (as shown in Tables 6, 7, 8, 9). Both RB and BR genotype chickens showed significantly higher $(p<0.01)$ carcass yield \% (in male and females) than BB and RR genotypes. Males of RB and BR genotypes showed higher ( $p<0.01$ ) breast weight, drumstick weight, and thigh weight whereas females of the RB and BR genotypes showed higher $(\mathrm{p}<0.05)$ heart weight compared with BB and RR genotypes. Males of RB genotype showed higher ( $p<0.01$ ) heart weight, intestinal length, and intestinal weight than that of BR, RR and BB genotypes.Gizzard weight was found to be higher $(p<0.05)$ in BR genotype chickens (in both males and females). Females of BR genotype chickens showed higher $(\mathrm{P}<0.05)$ breast weight, intestinal length, wing weight, drumstick weight, and thigh weight. BB chickens showed lowest (males, $\mathrm{p}<0.01$ and females, $\mathrm{p}<0.05$ ) liver weight in both sexes. Although not significant $(p>0.05)$, differences were observed in the 
Table 4. Effect of Production system, genotype and their interaction on male morphometric measurements at $16^{\text {th }}$ week of age.

\begin{tabular}{|c|c|c|c|c|c|c|c|c|c|}
\hline 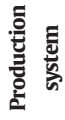 & 芦 & BW & BL & DC & DL & $\mathbf{K L}$ & SC & SL & WS \\
\hline $\mathrm{CC}$ & & $1420.05 \pm 8.44^{b}$ & $62.10 \pm 1.26$ & $7.86 \pm 0.20^{\mathrm{ab}}$ & $11.36 \pm 0.16^{\mathrm{ab}}$ & $10.54 \pm 0.22$ & $3.96 \pm 0.09$ & $9.40 \pm 0.25$ & $8.88 \pm 0.20^{\mathrm{b}}$ \\
\hline $\mathrm{AV}$ & & $1376.86 \pm 6.87^{c}$ & $58.05 \pm 2.33$ & $7.47 \pm 0.20^{\mathrm{b}}$ & $11.07 \pm 0.20^{\mathrm{b}}$ & $10.30 \pm 0.16$ & $3.74 \pm 0.07$ & $9.61 \pm 0.13$ & $9.63 \pm 0.20^{\mathrm{a}}$ \\
\hline EC & & $1453.52 \pm 11.94^{\mathrm{a}}$ & $63.85 \pm 1.41$ & $8.20 \pm 0.21^{\mathrm{a}}$ & $11.80 \pm 0.17^{\mathrm{a}}$ & $10.69 \pm 0.17$ & $3.91 \pm 0.09$ & $9.81 \pm 0.24$ & $9.08 \pm 0.17^{b}$ \\
\hline \multicolumn{2}{|c|}{ P-value } & $<0.0001$ & 0.0599 & 0.0060 & 0.0064 & 0.2955 & 0.1699 & 0.3693 & 0.0187 \\
\hline & $\mathrm{RB}$ & $1453.61 \pm 12.93^{a}$ & $63.73 \pm 1.65$ & $8.52 \pm 0.19^{a}$ & $11.99 \pm 0.20^{\mathrm{a}}$ & $10.89 \pm 0.22^{\mathrm{a}}$ & $4.02 \pm 0.13$ & $10.01 \pm 0.25^{\mathrm{a}}$ & $9.42 \pm 0.07^{\mathrm{a}}$ \\
\hline & $\mathrm{RR}$ & $1398.93 \pm 8.74^{b}$ & $60.33 \pm 1.15$ & $7.42 \pm 0.21^{\mathrm{b}}$ & $11.12 \pm 0.07^{b}$ & $10.21 \pm 0.16^{b}$ & $3.78 \pm 0.09$ & $9.29 \pm 0.24^{\mathrm{b}}$ & $9.07 \pm 0.28^{\mathrm{ab}}$ \\
\hline & $\mathrm{BR}$ & $1447.64 \pm 11.80^{a}$ & $62.53 \pm 2.82$ & $8.41 \pm 0.17^{a}$ & $11.72 \pm 0.19^{\mathrm{a}}$ & $10.89 \pm 0.20^{\mathrm{a}}$ & $3.95 \pm 0.10$ & $9.91 \pm 0.24^{\mathrm{ab}}$ & $9.54 \pm 0.24^{\mathrm{a}}$ \\
\hline & BB & $1367.02 \pm 8.00^{c}$ & $58.73 \pm 0.23$ & $7.04 \pm 0.18^{b}$ & $10.81 \pm 0.25^{\mathrm{b}}$ & $10.04 \pm 0.20^{\mathrm{b}}$ & $3.72 \pm 0.04$ & $9.21 \pm 0.20^{\mathrm{b}}$ & $8.75 \pm 0.24^{b}$ \\
\hline \multicolumn{2}{|c|}{ P-value } & $<0.0001$ & 0.2994 & $<.0001$ & $<.0001$ & 0.0047 & 0.1244 & 0.0389 & 0.0505 \\
\hline $\mathrm{CC}$ & $\mathrm{RB}$ & $1424.77 \pm 15.63^{\mathrm{bcd}}$ & $60.00 \pm 1.64$ & $8.57 \pm 0.21^{\mathrm{abc}}$ & $11.75 \pm 0.32^{\mathrm{abc}}$ & $10.94 \pm 0.59$ & $3.95 \pm 0.30$ & $9.78 \pm 0.69^{\mathrm{ab}}$ & $9.39 \pm 0.11^{\mathrm{ab}}$ \\
\hline $\mathrm{CC}$ & $\mathrm{RR}$ & $1433.76 \pm 17.86^{\text {bc }}$ & $59.80 \pm 1.15$ & $7.45 \pm 0.28^{\mathrm{def}}$ & $11.12 \pm 0.08^{\mathrm{bcd}}$ & $10.20 \pm 0.29$ & $4.03 \pm 0.17$ & $8.92 \pm 0.58^{b}$ & $8.15 \pm 0.40^{c}$ \\
\hline $\mathrm{CC}$ & $\mathrm{BR}$ & $1446.57 \pm 17.62^{\mathrm{b}}$ & $66.00 \pm 3.34$ & $8.48 \pm 0.08^{\mathrm{abc}}$ & $11.69 \pm 0.34^{b c}$ & $10.96 \pm 0.37$ & $4.06 \pm 0.16$ & $9.24 \pm 0.45^{\mathrm{b}}$ & $9.18 \pm 0.42^{\mathrm{abc}}$ \\
\hline $\mathrm{CC}$ & BB & $1374.66 \pm 12.93^{\mathrm{de}}$ & $62.60 \pm 2.99$ & $6.95 \pm 0.40^{\text {ef }}$ & $10.88 \pm 0.42^{\mathrm{cd}}$ & $10.04 \pm 0.48$ & $3.81 \pm 0.11$ & $9.65 \pm 0.30^{\mathrm{ab}}$ & $8.82 \pm 0.44^{\mathrm{bc}}$ \\
\hline $\mathrm{AV}$ & $\mathrm{RB}$ & $1392.81 \pm 13.04^{\text {cde }}$ & $65.60 \pm 3.44$ & $8.01 \pm 0.40^{\mathrm{abcd}}$ & $11.51 \pm 0.32^{\mathrm{bc}}$ & $10.64 \pm 0.23$ & $3.88 \pm 0.14$ & $9.64 \pm 0.20^{\mathrm{ab}}$ & $9.41 \pm 0.22^{\mathrm{ab}}$ \\
\hline $\mathrm{AV}$ & $\mathrm{RR}$ & $1375.76 \pm 12.65^{\mathrm{de}}$ & $59.60 \pm 2.56$ & $7.19 \pm 0.50^{\text {def }}$ & $10.95 \pm 0.12^{\mathrm{cd}}$ & $10.03 \pm 0.33$ & $3.62 \pm 0.12$ & $9.70 \pm 0.32^{\mathrm{ab}}$ & $9.71 \pm 0.56^{\mathrm{ab}}$ \\
\hline $\mathrm{AV}$ & $\mathrm{BR}$ & $1393.79 \pm 11.64^{\text {cde }}$ & $57.40 \pm 6.91$ & $7.91 \pm 0.33^{\text {bcde }}$ & $11.46 \pm 0.31^{\mathrm{bc}}$ & $10.59 \pm 0.38$ & $3.77 \pm 0.20$ & $9.81 \pm 0.19^{\mathrm{ab}}$ & $10.09 \pm 0.50^{\mathrm{a}}$ \\
\hline $\mathrm{AV}$ & BB & $1345.14 \pm 15.64$ & $49.60 \pm 2.11$ & $6.78 \pm 0.21^{\mathrm{f}}$ & $10.37 \pm 0.62^{\mathrm{d}}$ & $9.94 \pm 0.31$ & $3.69 \pm 0.05$ & $9.29 \pm 0.37^{b}$ & $9.31 \pm 0.21^{\mathrm{ab}}$ \\
\hline $\mathrm{EC}$ & $\mathrm{RB}$ & $1537.96 \pm 23.68^{\mathrm{a}}$ & $65.60 \pm 2.97$ & $8.97 \pm 0.22^{\mathrm{a}}$ & $12.71 \pm 0.19^{\mathrm{a}}$ & $11.08 \pm 0.34$ & $4.24 \pm 0.22$ & $10.62 \pm 0.15^{\mathrm{a}}$ & $9.47 \pm 0.00^{\mathrm{ab}}$ \\
\hline EC & $\mathrm{RR}$ & $1388.36 \pm 11.99^{\text {cde }}$ & $61.60 \pm 2.33$ & $7.62 \pm 0.38^{\text {cdef }}$ & $11.29 \pm 0.16^{\mathrm{bcd}}$ & $10.40 \pm 0.28$ & $3.70 \pm 0.15$ & $9.26 \pm 0.29^{b}$ & $9.37 \pm 0.21^{\mathrm{ab}}$ \\
\hline EC & $\mathrm{BR}$ & $1502.57 \pm 23.51^{\mathrm{a}}$ & $64.20 \pm 3.81$ & $8.85 \pm 0.29^{\mathrm{ab}}$ & $12.02 \pm 0.36^{\mathrm{ab}}$ & $11.12 \pm 0.34$ & $4.03 \pm 0.20$ & $10.69 \pm 0.37^{a}$ & $9.37 \pm 0.26^{\mathrm{ab}}$ \\
\hline EC & BB & $1380.61 \pm 12.27^{\mathrm{de}}$ & $64.00 \pm 2.70$ & $7.37 \pm 0.29^{\text {def }}$ & $11.18 \pm 0.14^{\mathrm{bcd}}$ & $10.14 \pm 0.32$ & $3.67 \pm 0.06$ & $8.69 \pm 0.31^{\mathrm{b}}$ & $8.13 \pm 0.43^{c}$ \\
\hline \multicolumn{2}{|c|}{ p-value } & $<0.0001$ & 0.0545 & $<.0001$ & 0.0012 & 0.2005 & 0.3030 & 0.0184 & 0.0111 \\
\hline
\end{tabular}

Superscripts on means within columns differ significantly at probability $\leq 0.05$; Values explains Mean \pm Standard Errors; RR $=\mathrm{RNN} \times \mathrm{RNN}$ while RNN $=\mathrm{Rhode}$ Island Red $\times$ Naked Neck, BB $=$ BNN $\times$ BNN while BNN $=$ Black Australorp $\times$ Naked Neck, RB $=$ RNN $\times$ BNN, BR $=B N N \times$ RNN, EC $=$ Enriched cages, AV $=$ Aviary, CC $=$ Conventional cages; $\mathrm{BW}=$ body weight $(\mathrm{g}), \mathrm{BL}=$ Body length $(\mathrm{cm}), \mathrm{DC}=$ Drumstick circumference $(\mathrm{cm}), \mathrm{DL}=$ Drumstick length $(\mathrm{cm}), \mathrm{KL}=\mathrm{Keel}$ length $(\mathrm{cm}), \mathrm{SC}=\mathrm{Shank}$ circumference $(\mathrm{cm}), \mathrm{SL}=$ Shank length $(\mathrm{cm})$, WS $=$ Wing span $(\mathrm{cm})$.

wings weight of males and intestinal length of females among different genotypes.

Chickens reared in enriched cage system had higher ( $p<0.01$ ) breast weight, drumstick weight, thigh weight, and heart weight than those reared in the aviary and conventional cage system. Carcass yield was found to be $\operatorname{higher}(\mathrm{p}<0.01)$ in males reared in the aviary and enriched cages than those reared in conventional cages. Carcass yield and wings weight of females were highest $(p<0.05)$ in the aviary system followed by enriched and conventional cages. Gizzard weight was found to be higher $(p<0.01)$ in both sexes reared in conventional cages than those reared enriched and conventional cages. Liver weight of females was higher $(p<0.01)$ in the enriched and conventional cage than that of the aviary system while the liver weight of males was higher $(p<0.01)$ in chickens reared in enriched cages followed by conventional cages and aviary system. Although not significant ( $p>0.05$ ), differences were observed in the intestinal length of chickens reared in different production systems.

Significant interactions $(\mathrm{p}<0.05$ ) between genotype and production systems of males and females were observed in most of the carcass traits except intestinal length in which similar ( $p>0.05$ ) means (in males and females) of interactions were found. RB and BR genotypes chickens (both sexes, $\mathrm{p}<0.01$ ) in the enriched cage system showed higher breast weight. Higher gizzard weight was observed in chickens (both sexes $\mathrm{p}<0.05$ ) of BB genotype in conventional cages. Heart weight and intestinal weight of RB genotype chickens (both sexes) were higher $(\mathrm{p}<0.05)$ in the enriched cage system. Carcass yield \% of males from RB genotype was higher $(p<0.01)$ in the aviary system while carcass yield \% of females were higher $(p<0.01)$ in RB and BR genotypes in an aviary system. Drumstick and thigh weight of BR males were observed to be higher $(\mathrm{p}<0.01)$ in enriched cages. Wings and thigh weight of females were higher $(\mathrm{p}<0.05)$ in the BR genotype in conventional cages. Drumstick weight of females from RB and BR genotype reared in enriched cages and BR genotype in conventional cages were higher $(\mathrm{P}<0.05)$ than other interaction groups.

\section{Discussion}

The present study elaborates the genetic potential of different crossbred genotypes under production systems. 
Table 5. Effect of Production system, genotype and their interaction on female morphometric measurements at $16^{\text {th }}$ week of age.

\begin{tabular}{|c|c|c|c|c|c|c|c|c|c|}
\hline 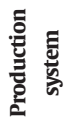 & 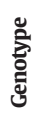 & BW & BL & DC & DL & $\mathbf{K L}$ & SC & SL & ws \\
\hline $\mathrm{CC}$ & & $1081.89 \pm 14.53^{b}$ & $56.70 \pm 1.31$ & $7.17 \pm 0.22^{\mathrm{ab}}$ & $10.32 \pm 0.39$ & $7.93 \pm 0.19^{\mathrm{ab}}$ & $3.28 \pm 0.08$ & $8.09 \pm 0.22$ & $7.85 \pm 0.25$ \\
\hline AV & & $1041.55 \pm 8.09^{c}$ & $54.80 \pm 1.60$ & $6.76 \pm 0.21^{\mathrm{b}}$ & $10.06 \pm 0.26$ & $7.62 \pm 0.14^{b}$ & $3.13 \pm 0.14$ & $8.30 \pm 0.22$ & $8.23 \pm 0.32$ \\
\hline EC & & $1120.70 \pm 16.71^{\mathrm{a}}$ & $57.90 \pm 1.29$ & $7.60 \pm 0.21^{\mathrm{a}}$ & $10.63 \pm 0.21$ & $8.18 \pm 0.18^{a}$ & $3.15 \pm 0.13$ & $8.01 \pm 0.25$ & $8.02 \pm 0.12$ \\
\hline \multicolumn{2}{|c|}{ P-value } & 0.0001 & 0.3128 & 0.013 & 0.3966 & 0.04 & 0.6282 & 0.6264 & 0.5775 \\
\hline & $\mathrm{RB}$ & $1121.70 \pm 21.16^{a}$ & $56.40 \pm 1.42$ & $7.61 \pm 0.23^{\mathrm{a}}$ & $10.84 \pm 0.30$ & $8.32 \pm 0.21^{\mathrm{a}}$ & $3.40 \pm 0.18$ & $8.76 \pm 0.31^{\mathrm{a}}$ & $8.24 \pm 0.30$ \\
\hline & $\mathrm{RR}$ & $1046.76 \pm 8.67^{\mathrm{b}}$ & $55.53 \pm 1.03$ & $6.94 \pm 0.28^{\mathrm{ab}}$ & $10.07 \pm 0.24$ & $7.58 \pm 0.15^{b}$ & $3.15 \pm 0.11$ & $7.91 \pm 0.31^{b}$ & $7.99 \pm 0.16$ \\
\hline & $\mathrm{BR}$ & $1130.35 \pm 19.32^{\mathrm{a}}$ & $57.80 \pm 2.21$ & $7.50 \pm 0.16^{a}$ & $10.69 \pm 0.52$ & $8.26 \pm 0.19^{a}$ & $3.22 \pm 0.12$ & $8.20 \pm 0.17^{\mathrm{ab}}$ & $8.11 \pm 0.34$ \\
\hline & BB & $1028.44 \pm 7.05^{\mathrm{b}}$ & $56.13 \pm 1.74$ & $6.64 \pm 0.25^{\mathrm{b}}$ & $9.74 \pm 0.16$ & $7.48 \pm 0.18^{\mathrm{b}}$ & $2.98 \pm 0.13$ & $7.67 \pm 0.17^{b}$ & $7.79 \pm 0.31$ \\
\hline \multicolumn{2}{|c|}{ P-value } & $<0.0001$ & 0.7994 & 0.009 & 0.0850 & 0.001 & 0.2458 & 0.0274 & 0.7359 \\
\hline $\mathrm{CC}$ & $\mathrm{RB}$ & $1144.02 \pm 39.14^{\mathrm{ab}}$ & $53.00 \pm 1.18$ & $7.53 \pm 0.34$ & $10.74 \pm 0.51$ & $8.33 \pm 0.51^{\mathrm{abc}}$ & $3.45 \pm 0.14$ & $8.49 \pm 0.54$ & $7.76 \pm 0.42$ \\
\hline CC & RR & $1031.66 \pm 13.10^{d}$ & $56.20 \pm 2.15$ & $6.99 \pm 0.52$ & $10.18 \pm 0.48$ & $7.58 \pm 0.22^{\mathrm{abcd}}$ & $3.45 \pm 0.18$ & $8.44 \pm 0.46$ & $7.70 \pm 0.20$ \\
\hline $\mathrm{CC}$ & BR & $1128.25 \pm 33.60^{\mathrm{abc}}$ & $60.00 \pm 3.34$ & $7.65 \pm 0.17$ & $10.72 \pm 1.50$ & $8.33 \pm 0.32^{\mathrm{abc}}$ & $3.17 \pm 0.12$ & $7.99 \pm 0.32$ & $8.42 \pm 0.56$ \\
\hline $\mathrm{CC}$ & BB & $1026.00 \pm 12.36^{\mathrm{d}}$ & $57.60 \pm 2.99$ & $6.5 \pm 0.52$ & $9.66 \pm 0.26$ & $7.47 \pm 0.34^{\text {bcd }}$ & $3.07 \pm 0.21$ & $7.46 \pm 0.36$ & $7.55 \pm 0.74$ \\
\hline AV & $\mathrm{RB}$ & $1040.37 \pm 16.48^{d}$ & $58.00 \pm 3.14$ & $7.19 \pm 0.38$ & $10.44 \pm 0.74$ & $8.09 \pm 0.15^{\text {abcd }}$ & $3.34 \pm 0.49$ & $9.17 \pm 0.26$ & $9.29 \pm 0.56$ \\
\hline AV & $\mathrm{RR}$ & $1032.96 \pm 11.78^{d}$ & $54.40 \pm 1.36$ & $6.54 \pm 0.51$ & $9.74 \pm 0.22$ & $7.23 \pm 0.28^{\mathrm{d}}$ & $3.06 \pm 0.17$ & $8.20 \pm 0.66$ & $7.87 \pm 0.29$ \\
\hline AV & BR & $1064.56 \pm 22.28^{\mathrm{cd}}$ & $55.00 \pm 4.84$ & $7.01 \pm 0.36$ & $10.48 \pm 0.71$ & $7.83 \pm 0.28^{\text {abcd }}$ & $3.05 \pm 0.12$ & $7.83 \pm 0.24$ & $8.02 \pm 0.90$ \\
\hline AV & BB & $1028.65 \pm 12.43^{d}$ & $51.80 \pm 2.92$ & $6.29 \pm 0.39$ & $9.57 \pm 0.28$ & $7.31 \pm 0.24^{\mathrm{cd}}$ & $3.06 \pm 0.30$ & $8.01 \pm 0.35$ & $7.75 \pm 0.65$ \\
\hline EC & RB & $1174.33 \pm 41.60^{\mathrm{a}}$ & $58.20 \pm 2.37$ & $8.12 \pm 0.46$ & $11.33 \pm 0.28$ & $8.53 \pm 0.37^{\mathrm{ab}}$ & $3.39 \pm 0.28$ & $8.61 \pm 0.76$ & $7.67 \pm 0.21$ \\
\hline EC & $\mathrm{RR}$ & $1077.03 \pm 18.34^{\mathrm{bcd}}$ & $56.00 \pm 2.07$ & $7.30 \pm 0.50$ & $10.29 \pm 0.53$ & $7.93 \pm 0.24^{\mathrm{abcd}}$ & $2.94 \pm 0.19$ & $7.09 \pm 0.37$ & $8.40 \pm 0.29$ \\
\hline $\mathrm{EC}$ & BR & $1198.23 \pm 37.42^{\mathrm{a}}$ & $58.40 \pm 3.65$ & $7.85 \pm 0.18$ & $10.89 \pm 0.36$ & $8.63 \pm 0.34^{a}$ & $3.45 \pm 0.33$ & $8.77 \pm 0.22$ & $7.91 \pm 0.25$ \\
\hline EC & BB & $1030.66 \pm 12.46^{d}$ & $59.00 \pm 2.70$ & $7.14 \pm 0.38$ & $9.99 \pm 0.35$ & $7.66 \pm 0.42^{\mathrm{abcd}}$ & $2.83 \pm 0.21$ & $7.56 \pm 0.10$ & $8.08 \pm 0.14$ \\
\hline \multicolumn{2}{|c|}{ p-value } & $<0.0001$ & 0.6797 & 0.07 & 0.6875 & 0.034 & 0.6881 & 0.0588 & 0.5173 \\
\hline
\end{tabular}

Superscripts on different means within columns differ significantly at probability $\leq 0.05$; Values explains Mean \pm Standard Errors; RR $=\mathrm{RNN} \times \mathrm{RNN}$ while RNN $=\mathrm{Rhode}$ Island Red $\times$ Naked Neck, $B B=B N N \times B N N$ while $B N N=$ Black Australorp $\times$ Naked Neck, $\mathrm{RB}=\mathrm{RNN} \times \mathrm{BNN}, \mathrm{BR}=\mathrm{BNN} \times \mathrm{RNN}, \mathrm{EC}=$ Enriched cages, $\mathrm{AV}=$ Aviary, $\mathrm{CC}=\mathrm{Conventional}$ cages; $\mathrm{BW}=$ body weight $(\mathrm{g}), \mathrm{BL}=$ Body length $(\mathrm{cm}), \mathrm{DC}=$ Drumstick circumference $(\mathrm{cm}), \mathrm{DL}=$ Drumstick length $(\mathrm{cm}), \mathrm{KL}=$ Keel length $(\mathrm{cm}), \mathrm{SC}=$ Shank circumference $(\mathrm{cm}), \mathrm{SL}=$ Shank length $(\mathrm{cm})$, WS= Wing span $(\mathrm{cm})$.

Table 6. Effect of Production system and genotype on male carcass traits at $16^{\text {th }}$ week of age.

\begin{tabular}{|c|c|c|c|c|c|c|c|c|c|}
\hline \multirow{2}{*}{ Trait } & \multicolumn{3}{|c|}{ Production System } & \multirow{2}{*}{ P-value } & \multicolumn{4}{|c|}{ Genotype } & \multirow{2}{*}{ p-value } \\
\hline & CC & AV & EC & & RB & $\mathbf{R R}$ & BR & BB & \\
\hline DW & $687.72 \pm 8.17$ & $713.95 \pm 11.49$ & $711.57 \pm 12.00$ & 0.0923 & $733.70 \pm 13.66^{\mathrm{a}}$ & $697.81 \pm 10.12^{\mathrm{bc}}$ & $715.79 \pm 11.41^{1 \mathrm{ab}}$ & $670.35 \pm 7.49^{c}$ & 0.0010 \\
\hline $\mathrm{CY}$ & $55.86 \pm 0.40^{\mathrm{b}}$ & $58.70 \pm 0.64^{\mathrm{a}}$ & $57.83 \pm 0.62^{\mathrm{a}}$ & 0.0004 & $59.13 \pm 0.84^{\mathrm{a}}$ & $56.61 \pm 0.47^{b}$ & $58.25 \pm 0.55^{a}$ & $55.85 \pm 0.63^{b}$ & 0.0004 \\
\hline LW & $24.22 \pm 1.22^{\mathrm{ab}}$ & $21.66 \pm 0.98^{\mathrm{b}}$ & $27.20 \pm 1.40^{\mathrm{a}}$ & 0.0039 & $27.27 \pm 1.17^{\mathrm{a}}$ & $24.58 \pm 1.17^{\mathrm{a}}$ & $24.79 \pm 1.96^{\mathrm{a}}$ & $20.80 \pm 1.18^{b}$ & 0.0088 \\
\hline HW & $5.85 \pm 0.36^{c}$ & $6.95 \pm 0.35^{b}$ & $8.04 \pm 0.32^{\mathrm{a}}$ & 0.0001 & $7.92 \pm 0.48^{\mathrm{a}}$ & $6.03 \pm 0.37^{c}$ & $7.38 \pm 0.37^{\mathrm{ab}}$ & $6.46 \pm 0.49^{\mathrm{bc}}$ & 0.0017 \\
\hline GW & $21.37 \pm 1.24^{\mathrm{a}}$ & $17.21 \pm 1.31^{\mathrm{b}}$ & $15.28 \pm 1.09^{b}$ & 0.0016 & $15.26 \pm 1.32^{\mathrm{b}}$ & $18.88 \pm 2.00^{\mathrm{ab}}$ & $16.81 \pm 1.29^{b}$ & $20.87 \pm 1.17^{\mathrm{a}}$ & 0.0237 \\
\hline BW & $113.55 \pm 3.79^{\mathrm{b}}$ & $118.27 \pm 2.76^{b}$ & $143.04 \pm 4.29^{a}$ & 0.0001 & $136.41 \pm 4.90^{\mathrm{a}}$ & $118.55 \pm 4.55^{\mathrm{b}}$ & $133.19 \pm 5.57^{a}$ & $111.64 \pm 4.55^{\mathrm{b}}$ & 0.0001 \\
\hline IW & $44.68 \pm 1.03^{b}$ & $47.04 \pm 1.00^{\mathrm{b}}$ & $52.67 \pm 1.78^{\mathrm{a}}$ & 0.0001 & $50.92 \pm 2.03^{\mathrm{a}}$ & $46.53 \pm 1.53^{\mathrm{bc}}$ & $50.25 \pm 1.79^{\mathrm{ab}}$ & $44.82 \pm 1.24^{c}$ & 0.0075 \\
\hline IL & $150.12 \pm 5.85$ & $139.37 \pm 4.75$ & $146.00 \pm 7.42$ & 0.3853 & $164.00 \pm 5.51^{\mathrm{a}}$ & $140.91 \pm 7.78^{b}$ & $143.91 \pm 7.30^{\mathrm{b}}$ & $131.83 \pm 4.00^{\mathrm{b}}$ & 0.0073 \\
\hline WW & $59.61 \pm 1.33^{b}$ & $69.61 \pm 1.01^{\mathrm{a}}$ & $65.97 \pm 1.43^{\mathrm{a}}$ & 0.0001 & $65.05 \pm 1.98$ & $65.49 \pm 1.58$ & $66.59 \pm 1.95$ & $63.13 \pm 2.06$ & 0.4228 \\
\hline DMW & $112.81 \pm 2.36^{b}$ & $116.63 \pm 2.78^{b}$ & $130.26 \pm 2.48^{\mathrm{a}}$ & 0.0001 & $125.26 \pm 3.19^{\mathrm{a}}$ & $117.46 \pm 2.83^{\mathrm{b}}$ & $125.41 \pm 3.63^{\mathrm{a}}$ & $111.48 \pm 3.47^{\mathrm{b}}$ & 0.0004 \\
\hline TW & $132.13 \pm 2.43^{\mathrm{b}}$ & $135.72 \pm 2.91^{\mathrm{b}}$ & $149.59 \pm 2.68^{\mathrm{a}}$ & 0.0001 & $144.74 \pm 3.28^{\mathrm{a}}$ & $136.81 \pm 2.91^{\mathrm{b}}$ & $144.71 \pm 3.87^{\mathrm{a}}$ & $130.33 \pm 3.52^{\mathrm{b}}$ & 0.0006 \\
\hline
\end{tabular}

Superscripts on means within rows differ significantly at probability $\leq 0.05$; Values explains Mean \pm Standard Errors; RR $=\mathrm{RNN} \times \mathrm{RNN}$ while RNN $=\mathrm{Rhode}$ Island Red $\times$ Naked Neck, BB= BNN $\times$ BNN while BNN $=$ Black Australorp $\times$ Naked Neck, RB $=$ RNN $\times$ BNN, BR $=$ BNN $\times$ RNN, EC = Enriched cages, AV= Aviary, CC $=$ Conventional cages; DW= Dressed weight $(\mathrm{g}), \mathrm{CY}=$ Carcass yield (\%), LW= Liver weight $(\mathrm{g}), \mathrm{HW}=$ Heart weight ( $\mathrm{g}$ ), GW= Gizzard weight (g), BW= Breast weight ( $\mathrm{g}$ ), IW= Intestinal Weight $(\mathrm{g})$, IL= Intestinal length $(\mathrm{cm})$, WW= Wings weight (g), DMW= Drumstick weight (g), TW= Thigh weight (g). 


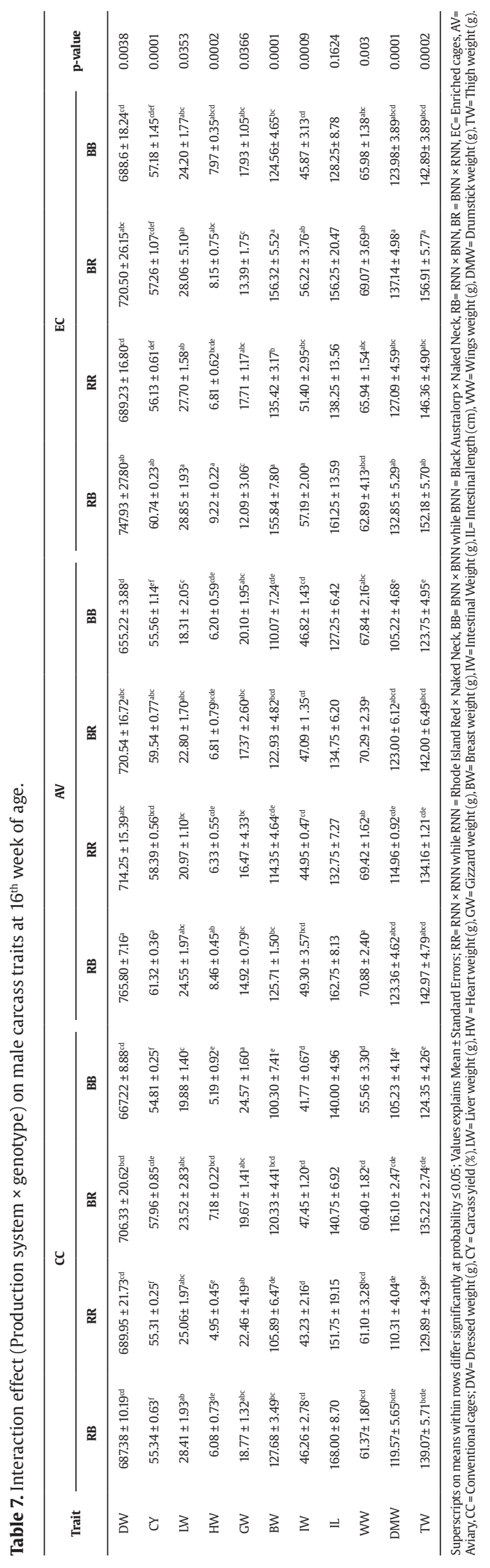


Table 8. Effect of Production system and genotype on female carcass traits at $16^{\text {th }}$ week of age.

\begin{tabular}{|c|c|c|c|c|c|c|c|c|c|}
\hline \multirow{2}{*}{ Trait } & \multicolumn{3}{|c|}{ Production System } & \multirow{2}{*}{ P-value } & \multicolumn{4}{|c|}{ Genotype } & \multirow{2}{*}{ p-value } \\
\hline & $\mathrm{CC}$ & AV & EC & & $\mathbf{R B}$ & $\mathbf{R R}$ & BR & BB & \\
\hline DW & $552.24 \pm 18.67$ & $542.62 \pm 8.58$ & $575.60 \pm 16.97$ & 0.221 & $568.81 \pm 19.99^{\mathrm{ab}}$ & $530.64 \pm 11.95^{b}$ & $602.59 \pm 20.29^{\mathrm{a}}$ & $525.24 \pm 7.08^{b}$ & 0.0033 \\
\hline $\mathrm{CY}$ & $55.50 \pm 0.37^{\mathrm{b}}$ & $58.27 \pm 0.91^{\mathrm{a}}$ & $56.88 \pm 0.63^{\mathrm{ab}}$ & 0.0045 & $58.65 \pm 0.94^{a}$ & $55.15 \pm 0.37^{\mathrm{b}}$ & $58.25 \pm 0.79^{a}$ & $55.47 \pm 0.61^{\mathrm{b}}$ & 0.0002 \\
\hline LW & $17.76 \pm 1.14^{\mathrm{a}}$ & $14.93 \pm 0.78^{\mathrm{b}}$ & $19.75 \pm 1.17^{\mathrm{a}}$ & 0.0048 & $19.01 \pm 0.97^{\mathrm{a}}$ & $17.55 \pm 1.13^{\mathrm{ab}}$ & $18.72 \pm 1.83^{\mathrm{a}}$ & $14.65 \pm 0.85^{\mathrm{b}}$ & 0.0374 \\
\hline HW & $4.30 \pm 0.39^{b}$ & $4.84 \pm 0.25^{b}$ & $5.87 \pm 0.29^{\mathrm{a}}$ & 0.0017 & $5.54 \pm 0.41^{\mathrm{a}}$ & $4.25 \pm 0.33^{b}$ & $5.60 \pm 0.39^{a}$ & $4.62 \pm 0.39^{\mathrm{ab}}$ & 0.0146 \\
\hline GW & $16.26 \pm 0.97^{\mathrm{a}}$ & $12.50 \pm 1.14^{\mathrm{b}}$ & $11.15 \pm 0.91^{\mathrm{b}}$ & 0.0011 & $10.56 \pm 1.01^{\mathrm{b}}$ & $13.77 \pm 1.45^{\mathrm{ab}}$ & $13.25 \pm 1.43^{\mathrm{ab}}$ & $15.62 \pm 0.95^{\mathrm{a}}$ & 0.0175 \\
\hline BW & $88.51 \pm 4.68^{b}$ & $87.15 \pm 1.68^{b}$ & $110.05 \pm 5.04^{\mathrm{a}}$ & 0.0001 & $100.71 \pm 5.77^{\mathrm{ab}}$ & $89.62 \pm 5.22^{\mathrm{bc}}$ & $106.02 \pm 5.69^{\mathrm{a}}$ & $84.58 \pm 3.44^{c}$ & 0.0023 \\
\hline IW & $35.29 \pm 1.51^{\mathrm{b}}$ & $35.24 \pm 0.80^{\mathrm{b}}$ & $41.11 \pm 2.22^{\mathrm{a}}$ & 0.0149 & $37.96 \pm 2.17$ & $35.84 \pm 2.27$ & $40.52 \pm 2.01$ & $34.54 \pm 1.11$ & 0.1149 \\
\hline IL & $116.06 \pm 3.63$ & $111.62 \pm 2.42$ & $116.25 \pm 3.49$ & 0.4859 & $107.41 \pm 4.12^{\mathrm{b}}$ & $115.00 \pm 2.75^{\mathrm{ab}}$ & $121.75 \pm 4.64^{\mathrm{a}}$ & $114.41 \pm 1.72^{\mathrm{ab}}$ & 0.0541 \\
\hline WW & $46.66 \pm 1.98^{b}$ & $51.96 \pm 1.11^{\mathrm{a}}$ & $50.44 \pm 1.17^{a b}$ & 0.0338 & $47.61 \pm 1.14^{b}$ & $49.70 \pm 1.86^{\mathrm{ab}}$ & $53.12 \pm 2.08^{a}$ & $48.31 \pm 1.72^{\mathrm{ab}}$ & 0.0993 \\
\hline DMW & $84.87 \pm 3.58^{\mathrm{b}}$ & $83.32 \pm 2.03^{\mathrm{b}}$ & $97.05 \pm 3.78^{a}$ & 0.0042 & $89.65 \pm 5.04^{\mathrm{ab}}$ & $85.64 \pm 3.24^{b}$ & $96.59 \pm 4.02^{\mathrm{a}}$ & $81.79 \pm 2.76^{b}$ & 0.0292 \\
\hline TW & $100.27 \pm 4.00^{\mathrm{b}}$ & $97.78 \pm 2.16^{\mathrm{b}}$ & $112.17 \pm 4.23^{\mathrm{a}}$ & 0.0096 & $104.26 \pm 5.49^{\mathrm{ab}}$ & $100.57 \pm 3.56^{\mathrm{b}}$ & $112.33 \pm 4.62^{\mathrm{a}}$ & $96.47 \pm 2.82^{\mathrm{b}}$ & 0.041 \\
\hline
\end{tabular}

Superscripts on means within rows differ significantly at probability $\leq 0.05$; Values explains Mean \pm Standard Errors; RR=RNN $\times$ RNN while RNN $=$ Rhode Island Red $\times$ Naked Neck, BB= BNN $\times$ BNN while BNN = Black Australorp $\times$ Naked Neck, RB= RNN $\times$ BNN, BR $=$ BNN $\times$ RNN, EC= Enriched cages, AV= Aviary, CC $=$ Conventional cages; $\mathrm{DW}=$ Dressed weight $(\mathrm{g}), \mathrm{CY}=$ Carcass yield (\%), LW= Liver weight ( $\mathrm{g}$ ), HW = Heart weight ( $\mathrm{g})$, GW= Gizzard weight ( $\mathrm{g}$ ), BW= Breast weight ( $\mathrm{g}$ ), IW= Intestinal Weight (g), IL= Intestinal length (cm), WW= Wings weight (g), DMW= Drumstick weight (g), TW= Thigh weight ( $\mathrm{g}$ is the unit of thigh weight).

On a general basis, higher body weight and morphometric traits were observed to be higher in the enriched cage system followed by conventional cage and aviary systems. Higher body weight in the enriched cage system might be ascribed by the provision of dust bathing and perching space thus providing more countenance of natural behaviors and less moving space. This prevents the burning of nutrients when compared with the aviary system in which the active behavior of birds causes more utilization of nutrients. Higher wing spread in the aviary system might be attributed to the higher wing flapping exercises which ultimately affects wings growth and development. Similar findings have been reported by Stadig et al. (2016) who observed lighter body weight of slow growing broilers in a free range system. Contrary findings have been reported by Ahmad et al. (2019) who observed improved morphometric traits due to more exercise in free range and semi intensive systems. As far as genotypes are concerned, BR and RB genotypes showed higher body weight, keel length, drumstick length and circumference, wingspread and shank length compared with RR and BB genotypes on an overall basis. This might be attributed to the additive gene action in RB and BR genotypes as RB and BR genotypes were crossbred of BNN and RNN genotypes which were obtained by cross breeding of Rhode Island Red, Black Australorp and Naked Neck. Rhode Island Red and Black Australorp are considered as heavier breeds because of their higher adult body weights (approximately 3-4 kg). In the previous study, body weight of Naked Neck was improved by crossing with Black Australorp and Rhode Island Red (Ahmad et al., 2019). Results of the present study revealed that body weight further increased in the second generation after crossing in a reciprocal way. Genes from three different breeds might be combined after heterosis and enhanced the effect of additive gene action. Improved morphometric traits from RB and BR genotypes might be due to the higher body weight of these breeds as improved body measurements are associated with higher body weights. Similar findings have been reported by Ahmad et al. (2019) who observed improvement in body weight and morphometric traits after crossbreeding between Rhode Island Red, Black Australorp and Naked Neck chickens. Fadare (2014) observed differences in morphological traits in the normal feathered, naked neck and frizzled feathered chickens when crossed with GiriRaja breed.Dissimilarities in morphometric traits among different varieties of Pakistani Aseel breed have also been elaborated by Qureshi et al. (2018).

Comparison of different genotypes in terms of carcass traits revealed that RB and BR genotype chickens showed better carcass yield \%, breast weight, drumstick weight and thigh weight.This might be attributed to the faster growth pattern of these genotype chickens as these breeds exhibited higher body weights as well. Higher carcass yield \%, breast weight, thigh weight and drumstick weight associated with better meat deposition which might also be concomitant with the wider breasts and substantial thigh muscles of Rhode Island Red and Black Australorp. Differences in carcass parameters are due to developed leg and breast muscle yield in slow growing chicken might be ascribed to larger muscle fibers that if attained by muscle fiber hypertrophy (Tang et al., 2009; Kim et al., 2013). These findings are corresponding to the outcomes of Devatkal et al. (2018) who observed differences in carcass parameters of meat type chickens. Ahmad et al. (2019) reported higher dressed weight, breast weight and carcass yield in the Naked neck and Rhode Island Red crossbreds whereas higher thigh weight and drumstick weight was observed in Naked Neck and Black Australorp crossbreds. Variations in carcass traits among indigenous Thai chicken and crossbreds have also been reported by Jaturasitha et al. (2008). Regarding production systems, chickens reared in enriched cages showed higher breast weight, drumstick weight and thigh weight which reveals 


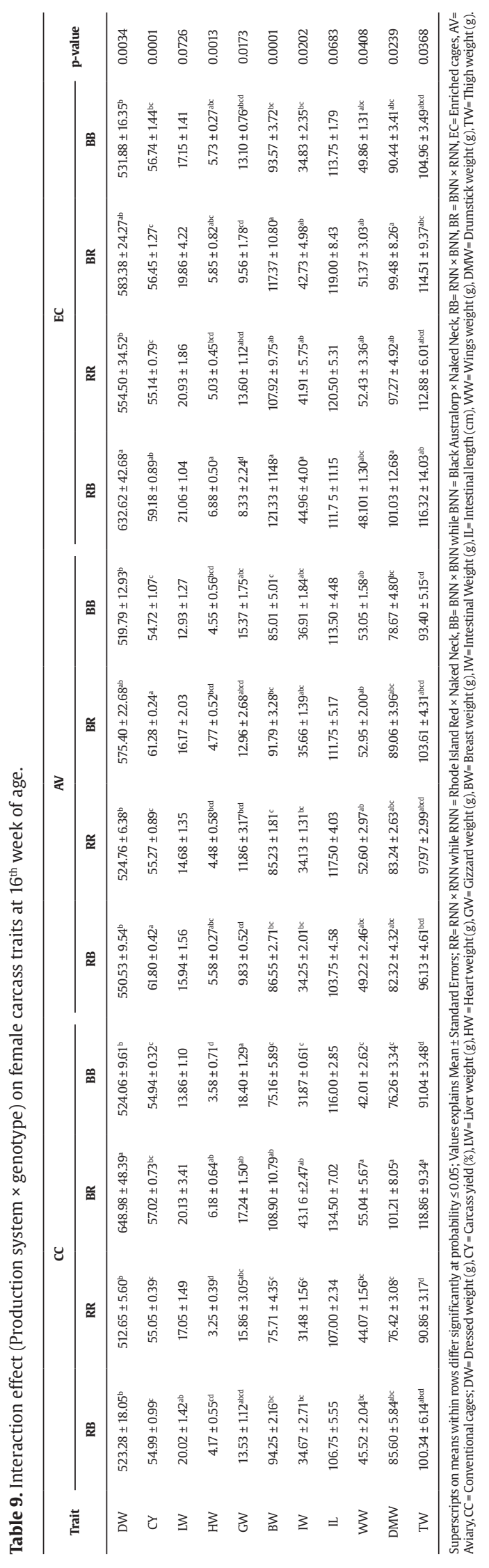


better development of skeletal muscles and meat yield. This might be attributed to the faster growth as chickens reared in enriched cages unveiled higher body weight. A possible reason behind the faster growth and muscle development of chickens in enriched cages is the activity level. Enriched cage is the compact package with sufficient stocking density for chickens equipped with utensils to express natural behavior in terms of perching and dust bathing for welfare aspects. So, this system restricted the unwanted movements and provided gears necessary to express natural comportment. This resulted in reduced cage stress with the least nutrient utilization on spontaneous activities and ultimately reinforced to enhance growth and muscle development. Association of activity and carcass traits has also been elaborated by Tong et al. (2014) in which they reported a linear increase in breast muscles and linear decrease in leg, thigh and foot yield with increasing free-range duration. Ahmad et al. (2019) reported higher carcass yield in chickens reared in the free range system when compared with intensive and semi intensive system. They explained that this variation might be due to the level of activity in outdoor excess. Improved thigh and breast yield in Ross males, when provided with outdoor access, has been reported (Castellini et al., 2002). Improved carcass traits of chickens given access to outdoor area boost their activity thus enhances comfort and welfare (Martínez-Pérez et al., 2017).

It is concluded that chickens (both sexes) of BR and RB genotypes had better morphological measurements and carcass traits than those of RR and BB genotype chickens. Among alternative production systems, chickens reared in enriched cages had better traits than those reared in conventional cages and aviary during the growing phase.

\section{Acknowledgements}

Authors gratefully acknowledge the administration of Indigenous Chicken Genetic Resource Centre, Department of Poultry Production, University of Veterinary and Animal Sciences, Lahore, Pakistan.

\section{References}

ADEBAMBO, A.O., IKEOBI, C.O.N., OZOJE, M.O., ODUGUWA, O.O. and ADEBAMBO OLUFUNMILAYO, A., 2011. Combining abilities of growth traits among pure and crossbred meat type chickens. Archivos de Zootecnia, vol. 60, no. 232, pp. 953-963. http:// dx.doi.org/10.4321/S0004-05922011000400012.

AHMAD, S., MAHMUD, A., HUSSAIN, J. and JAVED, K., 2019. Morphological and carcass traits of three chicken genotypes under free-range, semiintensive, and intensive housing systems. Turkish Journal of Veterinary and Animal Sciences, vol. 43, no. 3, pp. 342-352. http://dx.doi.org/10.3906/vet-1902-9.

APPLEBY, M.C., 2003. The European Union ban on conventional cages for laying hens: history and prospects. Journal of Applied Animal Welfare Science, vol. 6, no. 2, pp. 103-121. http://dx.doi. org/10.1207/S15327604JAWS0602_03. PMid:12909526.

BATOOL, T., FAROOQ S., ROOHI, N., MAHMUD, A., USMAN, M., GHAYAS, A. and AHMAD, S., 2018. Effect of different dietary lysine regimens on meat quality attributes in varieties of indigenous Aseel chicken. Kafkas Üniversitesi Veteriner Fakültesi Dergisi, vol. 24, no. 5, pp. 639-645. http://dx.doi.org/10.9775/ kvfd.2018.19523.

BUNGSRISAWAT, P., TUMWASORN, S., LOONGYAI, W., NAKTHONG, S. and SOPANNARATH, P., 2018. Genetic parameters of some carcass and meat quality traits in Betong chicken (KU line). Agriculture and Natural Resources, vol. 52, no. 3, pp. 274-279. https://doi.org/10.1016/j.anres.2018.09.010.

CASTELLINI, C., MUGNAI, C. and DAL BOSCO, A., 2002. Effect of organic production system on broiler carcass and meat quality. Meat Science, vol. 60, no. 3, pp. 219-225. http://dx.doi. org/10.1016/S0309-1740(01)00124-3. PMid:22063392.

DEVATKAL, S.K., VISHNURAJ, M.R., KULKARNI, V.V. and KOTAIAH, T., 2018. Carcass and meat quality characterization of indigenous and improved variety of chicken genotypes. Poultry Science, vol. 97, no. 8, pp. 2947-2956. http://dx.doi.org/10.3382/ps/ pey108. PMid:29762770.

EUSEMANN, B.K., PATT, A., SCHRADER, L., WEIGEND, S., THÖNEREINEKE, C. and PETOW, S., 2020. The role of egg production in the etiology of keel bone damage in laying hens. Frontiers in Veterinary Science, vol. 7, pp. 81. http://dx.doi.org/10.3389/ fvets.2020.00081. PMid:32154276.

FADARE, A.O., 2014. Morphometric and growth performance variations of naked neck, frizzled feathered and normal feather crosses with exotic Giri-raja chickens. Jordan Journal of Agricultural Sciences, vol. 10, no. 4, pp. 811-820. http://dx.doi. org/10.12816/0031774.

GHAYAS, A., HUSSAIN, J., MAHMUD, A. and JASPAL, M.H., 2020. Evaluation of three fast- and slow-growing chicken strains reared in two production environments. South African Journal of Animal Science, vol. 50, no. 3, pp. 378-388. http://dx.doi. org/10.4314/sajas.v50i3.4.

HARTCHER, K.M. and LUM, H.K., 2020. Genetic selection of broilers and welfare consequences: a review. World's Poultry Science Journal, vol. 76, no. 1, pp. 154-167. http://dx.doi.org/10.1080/ 00439339.2019.1680025.

HAVENSTEIN, G.B., FERKET, P.R. and QURESHI, M.A., 2003a. Carcass composition and yield of 1957 versus 2001 broilers when fed representative 1957 and 2001 broiler diets. Poultry Science, vol. 82, no. 10, pp. 1509-1518. http://dx.doi.org/10.1093/ ps/82.10.1509. PMid:14601726.

HAVENSTEIN, G.B., FERKET, P.R. and QURESHI, M.A., 2003b. Growth, livability and feed conversion of 1957 versus 2001 broilers when fed representative 1957 and 2001 broiler diet. Poultry Science, vol. 82, no. 10, pp. 1500-1508. http://dx.doi.org/10.1093/ ps/82.10.1500. PMid:14601725.

HY-LINE. [viewed 25 May 2021]. Hy-line W-36. Commercial layers management guide [online]. 2018. Available from: https://www. hyline.com/UserDocs/Pages/36_COM_ENG.pdf

JATURASITHA, S., KAYAN, A. and WICKE, M., 2008. Carcass and meat characteristics of male chickens between Thai indigenous compared with improved layer breeds and their crossbred. Archiv fur Tierzucht, vol. 51, no. 3, pp. 283-294. http://dx.doi. org/10.5194/aab-51-283-2008.

KHAWAJA, T., KHAN, S.H., MUKHTAR, N., PARVEEN, A. and AHMED, T., 2013. Comparative study of growth performance, meat quality and haematological parameters of three-way crossbred chickens with reciprocal F1 crossbred chickens in a subtropical environment. Journal of Applied Animal Research, vol. 41, no. 3, pp. 300-308. http://dx.doi.org/10.1080/09712119.2013.782869.

KIM, G.D., KIM, B.W., JEONG, J.Y., HUR, S.J., CHO, C., LIM, H.T. and JOO, S.T., 2013. Relationship of carcass weight to muscle fiber characteristics and pork quality of crossbred (Korean native 
black pig $\times$ Landrace) F2 pigs. Food and Bioprocess Technology, vol. 6, no. 2, pp. 522-529. http://dx.doi.org/10.1007/s11947011-0724-2.

LEESON, S. and SUMMERS, J.D., 2005. Commercial poultry nutrition. 3rd ed. Nottingham, UK: Nottingham University Press, pp. 297-305.

LEYENDECKER, M., HAMANN, H., HARTUNG, J., KAMPHUES, J., NEUMANN, U., SÜRIE, C. and DISTL, O., 2005. Keeping laying hens in furnished cages and an aviary housing system enhances their bone stability. British Poultry Science, vol. 46, no. 5, pp. 536-544. http://dx.doi.org/10.1080/00071660500273094. PMid:16359105.

MELESSE, A., MAAK, S., SCHMIDT, R. and VON LENGERKEN, G., 2011. Effect of long-term heat stress on some performance traits and plasma enzyme activities in Naked-neck chickens and their F1 crosses with commercial layer breeds. Livestock Science, vol. 141, no. 2-3, pp. 227-231. http://dx.doi.org/10.1016/j. livsci.2011.06.007.

NDEGWA, J.M. and KIMANI, C.W., 1997. Rural poultry production in Kenya: research and development strategies. In: Proceedings of the 5th Kenya Agricultural Research Institute Conference, 1997, Nairobi, Kenya. Nairobi, Kenya: Kenya Agricultural Research Institute.

OKENO, T.O., KAHI, A.K. and PETERS, K.J., 2011. Breed selection practices and traits of economic importance for indigenous chicken in Kenya. Livestock Research for Rural Development, vol. 23, pp. 10.

POHLE, K. and CHENG, H.W., 2009. Comparative effects of furnished and battery cages on egg production and physiological parameters in White Leghorn hens. Poultry Science, vol. 88, no. 10, pp. 2042-2051. http://dx.doi.org/10.3382/ps.2009-00171. PMid:19762855.

PREISINGER, R., 2005. Development, state and perspectives of poultry production. Züchtungskunde, vol. 77, pp. 502-507.

QURESHI, M., QADRI, A.H. and GACHAL, G.S., 2018. Morphological study of various varieties of Aseel chicken breed inhabiting district Hyderabad. Journal of Entomology and Zoology Studies, vol. 6, no. 2, pp. 2043-2045.

RAPHULU, T., VAN RENSBERG, C.J. and COERTZE, R.J., 2015. Carcass composition of Venda indigenous scavenging chickens under village management. Journal of Agriculture and Rural Development in the Tropics and Subtropics, vol. 116, no. 1, pp. 27-35.
ROWLAND, K., ASHWELL, C.M., PERSIA, M.E., ROTHSCHILD, M.F., SCHMIDT, C. and LAMONT, S.J., 2019. Genetic analysis of production, physiological, and egg quality traits in heatchallenged commercial white egg-laying hens using 600k SNP array data. Genetics, Selection, Evolution., vol. 51, no. 1, pp. 31. http://dx.doi.org/10.1186/s12711-019-0474-6. PMid:31238874.

SADEF, S., KHAN, M.S. and REHMAN, M.S., 2015. Indigenous chicken production in Punjab: A detailed survey through participatory rural appraisals. Journal of Animal and Plant Sciences, vol. 25, pp. 1273-1282.

SOSNÓWKA-CZAJKA, E., HERBUT, E. and SKOMORUCHA, I., 2010. Effect of different housing systems on productivity and welfare of laying hens. Annals of Animal Science, vol. 10, pp. 349-360.

STADIG, L.M., RODENBURG, T.B., REUBENS, B., AERTS, J., DUQUENNE, B. and TUYTTENS, F.A.M., 2016. Effects of free-range access on production parameters and meat quality, composition and taste in slow-growing broiler chickens. Poultry Science, vol. 95, no. 12, pp. 2971-2978. http://dx.doi.org/10.3382/ps/pew226. PMid:27486253.

TALLENTIRE, C.W., LEINONEN, I. and KYRIAZAKIS, I., 2016. Breeding for efficiency in the broiler chicken: A review. Agronomy for Sustainable Development, vol. 36, no. 4, pp. 66. http://dx.doi. org/10.1007/s13593-016-0398-2.

TANG, H., GONG, Y.Z., WU, C.X., JIANG, J., WANG, Y. and LI, K., 2009. Variation of meat quality traits among five genotypes of chicken. Poultry Science, vol. 88, no. 10, pp. 2212-2218. http://dx.doi. org/10.3382/ps.2008-00036. PMid:19762878.

TERFA, Z.G., GARIKIPATI, S., KASSIE, G.T., DESSIE, T. and CHRISTLEY, R.M., 2019. Understanding farmers' preference for traits of chickens in rural Ethiopia. Agricultural Economics, vol. 50, no. 4, pp. 451-463. http://dx.doi.org/10.1111/agec.12502.

TONG, H.B., WANG, Q., LU, J., ZOU, J.M., CHANG, L.L. and FU, S., 2014. Effect of free-range days on a local chicken breed: growth performance, carcass yield, meat quality, and lymphoid organ index. Poultry Science, vol. 93, no. 8, pp. 1883-1889. http://dx.doi. org/10.3382/ps.2013-03470. PMid:24931968.

TUKEY, J.W., 1953. The Collected Works of John W. Tukey, VIII. Multiple Comparisons. New York, NY, USA: Chapman and Hall.

USMAN, M., MAHMUD, A., HUSSAIN, J. and JAVID, A., 2020. Performance of Rhode Island Red, black Australorp and Naked Neck crossbreds under alternative production systems. South African Journal of Animal Science, vol. 50, no. 4, pp. 565-577. http://dx.doi.org/10.4314/sajas.v50i4.8. 